\title{
Accurate classification of juvenile weakfish Cynoscion regalis to estuarine nursery areas based on chemical signatures in otoliths
}

\author{
Simon R. Thorrold ${ }^{1, *}$, Cynthia M. Jones ${ }^{1}$, Peter K. Swart ${ }^{2}$, Timothy E. Targett ${ }^{3}$ \\ ${ }^{1}$ Applied Marine Research Laboratory, Old Dominion University, Norfolk, Virginia 23529, USA \\ ${ }^{2}$ Division of Marine Geology and Geophysics, Rosenstiel School of Marine and Atmospheric Science, \\ University of Miami, 4600 Rickenbacker Causeway, Miami, Florida 33149, USA \\ ${ }^{3}$ Graduate College of Marine Studies, University of Delaware, Lewes, Delaware 19958, USA
}

\begin{abstract}
We investigated the ability of trace element and isotopic signatures in otoliths to record the nursery areas of juvenile (young-of-the-year) weakfish Cynoscion regalis from the east coast of the USA. Juvenile C. regalis were captured with otter trawls at multiple sites in Doboy Sound (Georgia), Panlico Sound (North Carolina), Chesapeake Bay (Virginia), Delaware Bay (Delaware) and Peconic Bay (New York), from July to September 1996. One sagittal otolith from each specimen was assayed for $\mathrm{Mg} / \mathrm{Ca}, \mathrm{Mn} / \mathrm{Ca}, \mathrm{Sr} / \mathrm{Ca}$ and $\mathrm{Ba} / \mathrm{Ca}$ ratios using inductively coupled plasma mass spectrometry (ICP$\mathrm{MS}$ ), while $\delta^{13} \mathrm{C}$ and $\delta^{18} \mathrm{O}$ values from the other sagittal otolith in the pair were determined using isotope ratio mass spectrometry (IR-MS). A multivariate analysis of variance determined that there were significant differences in trace element signatures among locations. Bootstrapped $95 \%$ confidence ellipses on canonical variates indicated that all 5 locations were significantly isolated in discriminant space. On the basis of these differences, linear discriminant function analysis (LDFA) and artificial neural network (ANN) models were used to classify individual fish to their natal estuary with an overall error rate of $37 \%$ for LDFA and $29.6 \%$ for ANN. Addition of $\delta^{13} \mathrm{C}$ and $\delta^{18} \mathrm{O}$ values to the LDFA and ANN models derived from the trace element data resulted in overall error around $10 \%$. We will, therefore, be able to use chemical signatures from the juvenile portion of adult $C$. regalis otoliths to accurately classify these fish to their natal estuary.
\end{abstract}

KEY WORDS: Estuarine nursery areas · Otolith chemistry · Trace elements · Stable isotopes · Neural networks

\section{INTRODUCTION}

Weakfish Cynoscion regalis landings along the Atlantic coast of the United States have recently shown a significant decline, with estimated commercial and recreational catches falling from $36 \times 10^{6} \mathrm{~kg}$ in 1980 to $3.6 \times 10^{6} \mathrm{~kg}$ in 1994. Efforts to manage this fishery are, however, handicapped by an inability to determine the spatial extent of weakfish stocks. The potential for presumptive stock mixing during over-wintering off the North Carolina coast has led to concerns that winter fisheries off North Carolina have been at least partly

\footnotetext{
·E-mail: sthorrol@odu.edu
}

responsible for the decline of the weakfish catch in northern waters. Juvenile weakfish also represent a significant component of the South Atlantic shrimp trawl bycatch (Vaughan et al. 1991). At present there is no way of determining the effect these fisheries are having on adult populations in more northern waters.

Previous studies based on mark-recapture, morphology and life history differences have suggested there may be multiple stocks of weakfish along the midAtlantic coast (reviewed by Graves et al. 1992). However, allozyme (Crawford et al. 1988) and mtDNA (Graves et al. 1992) studies failed to support a multistock hypothesis. Weakfish spawn in estuarine and near-coastal waters, and larvae are believed to use selective tidal stream transport to remain within the 
estuary in which they were spawned (Rowe \& Epifanio 1994). If larval drift is insignificant, and if spawning fish home to their natal area, weakfish should show evidence of stock separation along a geographic range that spans the entire U.S. Atlantic coast from Florida to Maine. However, the power of the genetic studies to test the null hypothesis of a single homogeneous stock was limited due to the low amount of overall genetic variation that was revealed. The mean nucleotide sequence diversity (the average amount of nucleotide differences found among individuals of a population) in the mtDNA analysis averaged $0.15 \%$, one of the lowest values reported for any vertebrate (Graves et al 1992). There is no way to determine, at this stage, if there is sufficient larval drift, or adult vagrancy, to prevent the formation of stock structure, or if the genetic techniques are not powerful enough to reveal what may be subtle genetic differences among adjacent populations.

Several recent studies have suggested that otoliths may be an ideal natural tag for studies of fish population structure and for tracking individual migration paths (Campana et al. 1995, Thorrold et al. 1997a). Otoliths form through concentric additions of aiternating protein and aragonite layers around a central nucleus. Because otoliths are acellular, once deposited, otolith material is neither resorbed nor metabolically reworked (Campana \& Neilson 1985). The chemical composition of the otolith reflects, in turn, the physical and chemical characteristics of the ambient water, albeit not necessarily in a simplistic manner (Fowler et al. 1995, Thorrold et al. 1997a). In principle, then, water mass differences at the time and place of hatching will be reflected in chemical composition differences in the otolith nucleus. By corollary, migration among water masses at some age or date will be recorded by the chemical composition of the otolith in the appropriate otolith increments

Most otolith chemistry studies have focused on quantifying elemental signatures of stock associations, with good success (e.g. Edmonds et al. 1989, 1991, 1992. Thresher et al. 1994, Campana et al. 1995\}. Signuficant information on environmental conditions may also reside, however, in carbon and oxygen stable isotope ratios within otoliths (e.g. Nelson et al. 1989, Patterson et al. 1993). For instance, Thorrold et al. (1997b) have shown that $\delta^{18} \mathrm{O}$ of juvenile Atlantic croaker Micropogonias undulatus is deposited in isotopic equilibrium with ambient water, and that the temperature fractionation relationship is similar to aragonite in hermatypic coral skeletons. On the basis of this temperature-dependent fractionation, Edmonds \& Fletcher (1997) suggested that $\delta^{18} \mathrm{O}$ values in otoliths of adult pilchards Sardinops sagax may be a useful tool for stock identification because populations largely reside in waters with differing thermal regimes. While carbon isotopes are not necessarily reflective of the carbon isotopic composition of dissolved inorganic carbon in the environment, changes in otolith $\delta^{13} \mathrm{C}$ may record geographic differences in growth and condition (Thorrold et al. 1997b)

In this study, we investigated the ability of trace element and stable isotope signatures in otoliths to act as natural tags of estuarine nursery areas in juvenile (young-of-the-year) weakfish Cynoscion regalis. The observation that $C$. regalis larvae are able to maintain themselves within the estuary system in which they were spawned minimized the possibility of juveniles collected in an estuarine nursery area originating from elsewhere (Rowe \& Epifanio 1994). The specific objectives of this study were to quantify geographic variation in the trace element and stable isotope chemistry of otoliths from juvenile $C$. regalis, and then to determine if these differences were sufficient to allow weakfish to be accurately classified to nursery areas based on these elemental and isotopic signatures.

\section{MATERIALS AND METHODS}

Juvenile weakfish were collected from 5 estuarine systems along the east coast of the United States, from Georgia to New York (Fig. 1). Within each location, fish were collected from several otter trawl sets at either 2 or 3 sites separated by at least $3 \mathrm{~km}$ (see Table 1), with the exception of Peconic Bay, where fish were collected from multiple tows and grouped into a single site. All samples were stored on ice in the field and subsequently frozen upon return to the lab. Surface and bottom temperature and salinity records were available from multiple sites at monthly intervals throughout the juvenile estuarine residency period for all locations except Pamlico Sound (Fig , 2).

In preparation for chemical analysis, sagittal otoliths were removed from the fish with acid-washed glass probes, placed in a drop of ultrapure (Milli-Q) water and cleaned of adhering tissue. Otoliths were then ultrasonically cleaned for $5 \mathrm{~min}$, rinsed in ultrapure $\mathrm{H}_{2} \mathrm{O}_{2}$ to remove any remaining tissue, triple-rinsed in Milli-Q water, and air-dried under a Class 100 laminar flow hood. After drying for at least $24 \mathrm{~h}$, otoliths were weighed to the nearest $10 \mu \mathrm{g}$ and stored in acidwashed high density polyethylene vials. Blank vials were similarly prepared for blank corrections and to calculate limits of detection. One of the otoliths was then used to determine elemental concentrations, while the other otolith in the pair was used for stable isotope analysis

Otolith chemistry analyses. Elemental concentrations in otoliths were determined by inductively cou- 


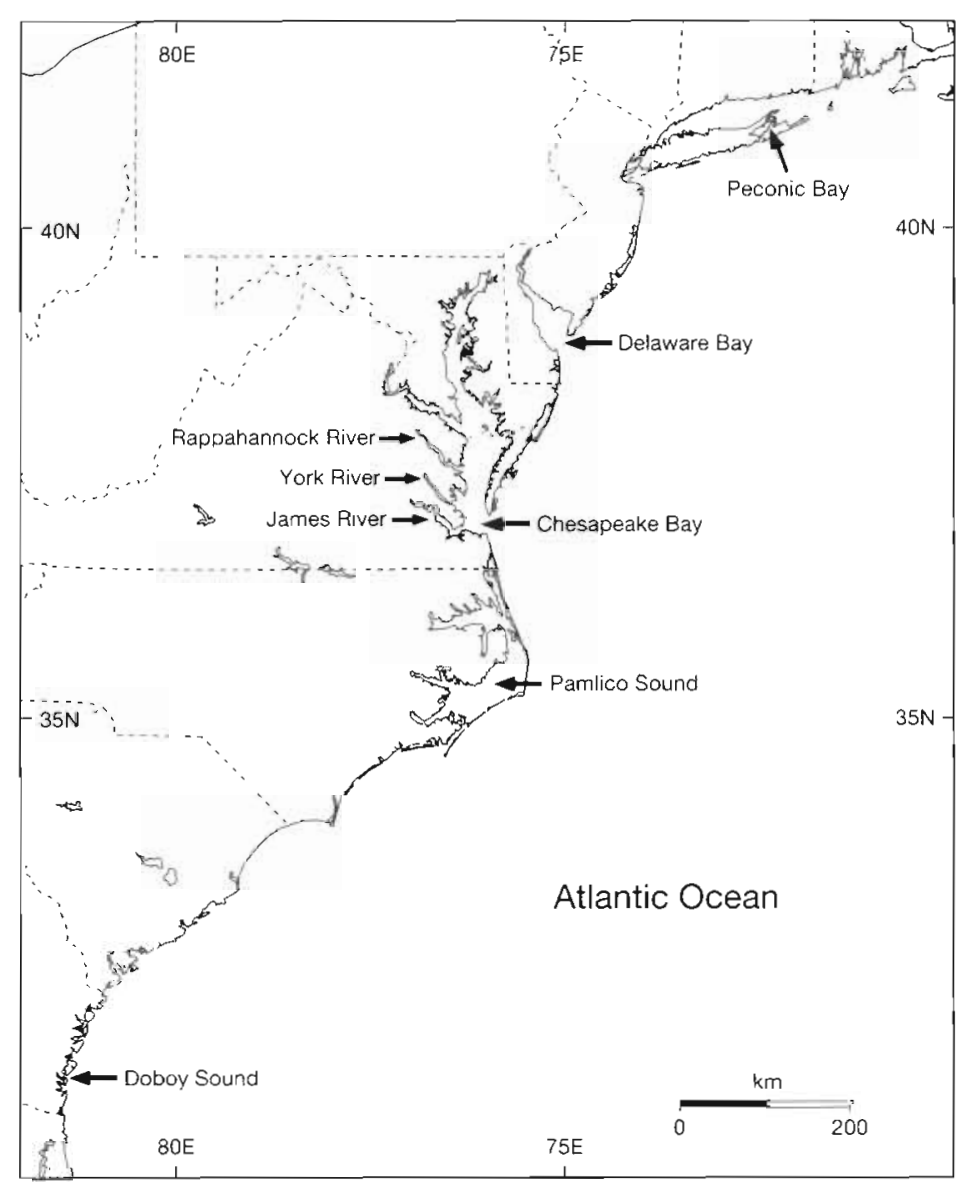

Fig. 1. Locality map showing sampling locations at Doboy Sound (Georgia), Pamlico Sound (North Carolina), Chesapeake Bay (Virginia), Delaware Bay (Delaware), and Peconic Bay (New York), USA
Otolith solutions were assayed with a Finnigan-MAT SOLA quadrupole ICP mass spectrometer. A lab standard, consisting of Micropogonias undulatus otoliths ground to micron-sized particles (Campana et al. 1997), was also assayed periodically throughout the otolith analysis to assess measurement repeatability. All elemental data were subsequently converted to molar concentrations and expressed as ratios to $\mathrm{Ca}$. Elements that substitute for $\mathrm{Ca}$ ions in the aragonite lattice may be expected to co-vary with elemental levels in the environment (Lea \& Boyle 1993). Incorporation of these elements in the otolith is more accurately standardized to the number of $\mathrm{Ca}$ ions in the otolith rather than on total otolith weight.

Limits of detection (LOD: $3 \sigma+$ mean blank value from 21 analyses of 7 blank vials) for each of the elements were as follows: $B$ $\left(4.54 \mu \mathrm{g} \mathrm{g}^{-1}\right), \mathrm{Mg}\left(3.99 \mu \mathrm{g} \mathrm{g} \mathrm{g}^{-1}\right), \mathrm{Ca}(253 \mu \mathrm{g}$ $\left.\mathrm{g}^{-1}\right), \mathrm{Mn}\left(0.87 \mu \mathrm{g} \mathrm{g}^{-1}\right)$, Zn (6.12 $\left.\mu \mathrm{g} \mathrm{g}^{-1}\right)$, Sr $\left(4.28 \mu \mathrm{g} \mathrm{g}^{-1}\right)$, and Ba $\left(0.08 \mu \mathrm{g} \mathrm{g}^{-1}\right)$. LODs were well below observed values for $\mathrm{Mg}, \mathrm{Ca}, \mathrm{Mn}$, $\mathrm{Sr}$ and $\mathrm{Ba}$. However, $\mathrm{B}$ and $\mathrm{Zn}$ counts were on occasion below detection limits. Estimates of precision (\%RSD) based on repeated analyses of our lab standard $(21$ analyses of $7 \mathrm{di}$ gests) were as follows: B/Ca $(80.7 \%), \mathrm{Mg} / \mathrm{Ca}$ $(8.9 \%), \mathrm{Mn} / \mathrm{Ca}(2.0 \%), \mathrm{Zn} / \mathrm{Ca}(29.4 \%), \mathrm{Sr} / \mathrm{Ca}$ $(4.8 \%)$ and $\mathrm{Ba} / \mathrm{Ca}(7.2 \%)$. We eliminated $\mathrm{B}$ and $\mathrm{Zn}$ from statistical analyses as levels of pled plasma mass spectrometry (ICP-MS). A preliminary study suggested 8 elements ( $B, M g, C a, M n, ~ Z n$, $\mathrm{Sr}, \mathrm{Ba}$ and $\mathrm{Pb}$ ) were detectable by ICP-MS in juvenile Cynoscion regalis otoliths, of which 5 were suitable for quantification by isotope dilution (B, Mg, $\mathrm{Zn}, \mathrm{Sr}$ and Ba). Isotope dilution (ID) is the preferred method of quantification due to superior accuracy and precision in otolith assays (Campana et al. 1995). While it is possible to perform Ca assays by isotope dilution ICP-MS, we adopted the technique described by Lea \& Martin (1996) whereby Ca is quantified using ${ }^{45} \mathrm{Sc}$ as an internal standard. Manganese is monoisotopic and consequently unsuitable for ID analysis and therefore was also quantified by normalizing counts to ${ }^{45} \mathrm{Sc}$. Otoliths were dissolved in $10 \%$ re-distilled nitric acid solution containing the enriched isotopes of the 5 elements targeted for isotope dilution, along with ${ }^{45} \mathrm{Sc}$. The enriched isotope spike solution contained ${ }^{10} \mathrm{~B},{ }^{25} \mathrm{Mg},{ }^{67} \mathrm{Zn}$, ${ }^{87} \mathrm{Sr}$, and ${ }^{137} \mathrm{Ba}$, while ${ }^{11} \mathrm{~B},{ }^{24} \mathrm{Mg},{ }^{66} \mathrm{Zn},{ }^{88} \mathrm{Sr}$ and ${ }^{138} \mathrm{Ba}$ were also monitored in the sample solutions for quantification.

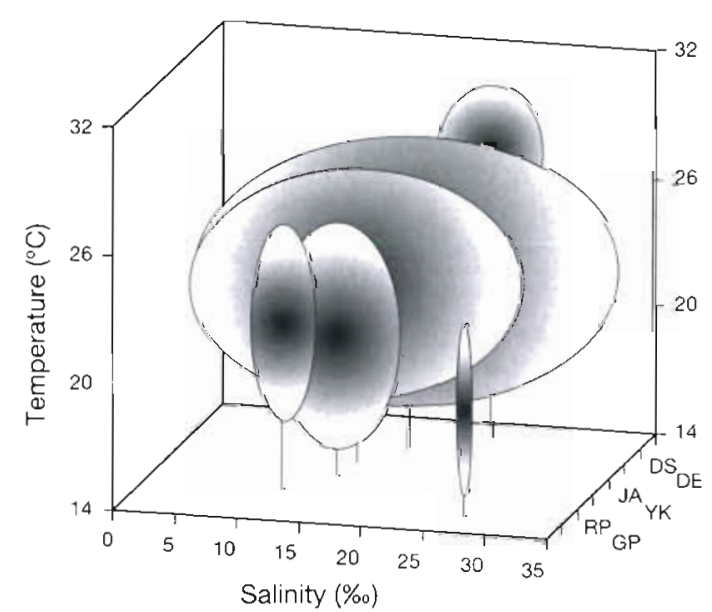

Fig. 2. Schematic of bottom temperature and salinity regimes from juvenile weakfish habitats in Doboy Sound (DS), Delaware Bay (DE), James River (JA), York River (YK), Rappahannock River (RP), and Peconic Bay (GP), from May until time of sample collections at each location. Ellipses represent temperature and salinity ranges at a number of sites from each location, and the ellipses are centered on mean values 
both elements were below the LOD in at least some of the samples, and because of the poor precision in repeated analyses of the lab standard.

Otoliths for carbon and oxygen isotope ratio analysis were processed by an automated carbonate device (common acid bath at $90^{\circ} \mathrm{C}$ ) attached to a FinniganMAT 251 gas ratio mass spectrometer. A number of otoliths were too large to be analyzed whole, so instead these otoliths were ground and a $1 \mathrm{mg}$ sample was then taken from the resulting otolith powder for stable isotope analysis. Data were corrected for the usual isobaric interferences, using the method of Craig (1957) modified for a triple collector mass spectrometer, and are expressed relative to PDB (Peedee Belemnite). External precision (calculated from replicate analyses of an internal laboratory calcite standard) was $0.02 \%$ for $\delta^{13} \mathrm{C}$ and $0.03 \%$ for $\delta^{18} \mathrm{O}$.

Data analysis. Statistical analyses of chemical signatures were carried out using parametric and non-parametric multivariate approaches. To test for the statistical significance of among-location differences in otolith chemistry while accounting for spatial variation within locations, we implemented a mixed-model MANOVA (multivariate analysis of variance) design with collection sites (a random term) nested within locations (a fixed term). Assumptions of multivariate normality and equal variance-covariance matrices were assessed by examining each of the univariate variables for normal distribution of errors and homogeneity of variances using residual analysis (Winer 1971). All variables met the assumptions for univariate ANOVA, and we therefore assumed that the multivariate tests would also be valid. The MANOVA was followed by a canonical discriminant analysis (CDA) to visualize differences among locations. A posteriori contrasts among locations were performed by calculating $95 \%$ confidence ellipses on class means using a bootstrap approach (Efron \& Gong 1983). Scores on each of the canonical variates were resampled 1000 times with replacement for the 5 locations. When confidence intervals were asymetric around class means, the largest of the 2 intervals was used to produce a conservative and symmetric confidence ellipse.

Linear discriminant function analysis (LDFA) was used to determine if chemical signatures in otoliths accurately record natal estuaries of juvenile Cynoscion regalis. The cross-validation algorithm in the SAS Institute Inc. (1990) DISCRIM procedure, which uses a jackknife technique, was used to determine classification accuracy. Each sample is removed sequentially from the data set, the discriminant function is estimated from the remaining samples, and then the function is used to classify the absent observation.

We also assessed the ability of artificial neural networks (ANN) to accurately classify fish to their natal estuary. Feed-forward neural networks are becoming increasingly popular in pattern recognition and classification applications in a number of scientific disciplines, including geology (Malmgren \& Nordlund 1996), population genetics (Cornuet et al. 1996), and ecology (Culverhouse et al. 1992). The neural network that we used consisted of an input matrix (the multivariate elemental data set) that passes to a single hidden layer after a tan-sigmoid transformation with a weight and bias term. The activity from the hidden neural layer is then passed through a simple linear transformation, with another weight and bias term, to the output layer consisting of a matrix that specifies the location to which an individual sample is to be classified (Fig. 3). The neural network is trained to classify individual samples by iteratively adjusting the weights and biases that connect each of the layers to minimize the model variance. After the network is adequately trained, it can then be used to classify unknown samples. In this instance, we used back-propagation to train the network, employing both momentum and adaptive learning rate to increase the speed and reliability of the back-propagation procedure (Demuth \& Beale 1994). All data were first standardized by subtracting the grand mean of the variable from each observation, and then dividing by the standard deviation. It is important to note that, unlike linear discriminant analysis, neural networks do not have a single statistical solution. Therefore, all analyses were run with 5 different initial starting values, and results are means of the 5 model runs. Classification success was determined with the same cross-validation procedure used in the LDFA.

To determine the optimum number of neurons in the hidden layer, we generated a training data set from both the element/Ca ratios and the combined elemental and carbon and oxygen isotopic data. The data matrices were constructed by removing (by random selection) 12 samples from each location (approximately $20 \%$ of the total samples) as a test data set, while the remaining samples were used to train the neural network. We then tested the classification success of the ANN by running 10 independent trials for each model that had different numbers of neurons $(3,6,9,12,18,24$, and 30$)$ in the hidden layer. Error rates generally decreased with increasing number of neurons in both the elemental and the combined elemental and isotopic data sets (Fig. 4). However, minimum error rates in both runs were observed in ANNs with 18 neurons in the hidden layer, and therefore this configuration was used in all subsequent analyses. Finally, error rates in all runs decreased exponentially with increasing numbers of training cycles ('epochs'). We chose 1000 epochs as a reasonable balance between the decrease in error rate associated with in- 
Fig. 3. (a) Schematic representation of the architecture of a 2-layer back-propagation artificial neural network (ANN) in which the 4 element/Ca ratios in otolith samples enter the network, pass through a hidden layer with 7 neurons (note that the actual neural network used in this study has 18 hidden neurons), and then pass onto the output layer whose activity specifies the location to which an individual observation should be classified. (b) Schematic representation of the path of a single observation through the neural network, in which the initial input value (i) is multiplied by a weight $\left(w_{n}\right)$ and then passed through a sigmoidal transfer function before the addition of a bias term $\left(b_{n}\right)$. The resulting neural activity (a), is then multiplied by another weight term $\left(w_{n+1}\right)$, passed through a linear transfer function, and a second bias term is added $\left(b_{n+1}\right)$; the resulting activity of the second neuron is the model output (o)

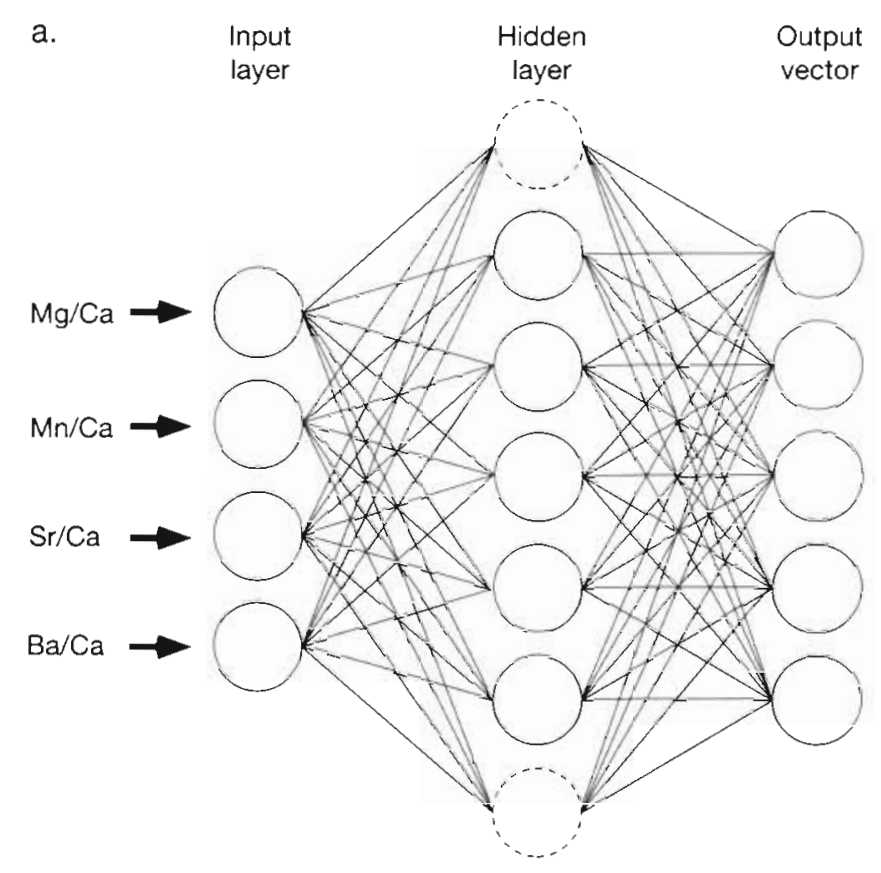

b.

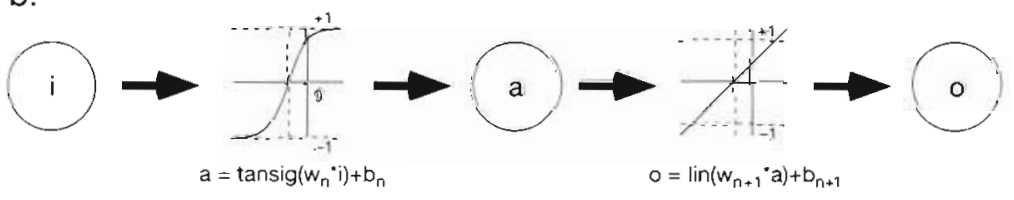

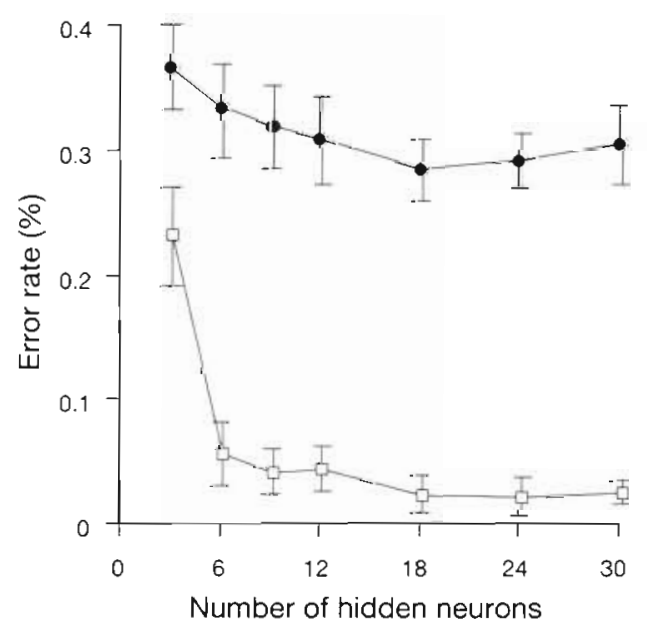

Fig. 4. Change in error rate for a 2-layer back-propagation neural network, trained with a subset (approximately $80 \%$ of original observations\} data matrix consisting of 4 element/Ca ratios (-) and the combined elemental and isotopic data (ㅁ) and then tested with the remaining $20 \%$ of the original observations, when the number of neurons in the hidden layer is increased from 3 to 30 . Error rates are means \pm SD from 10 independent runs of the neural network

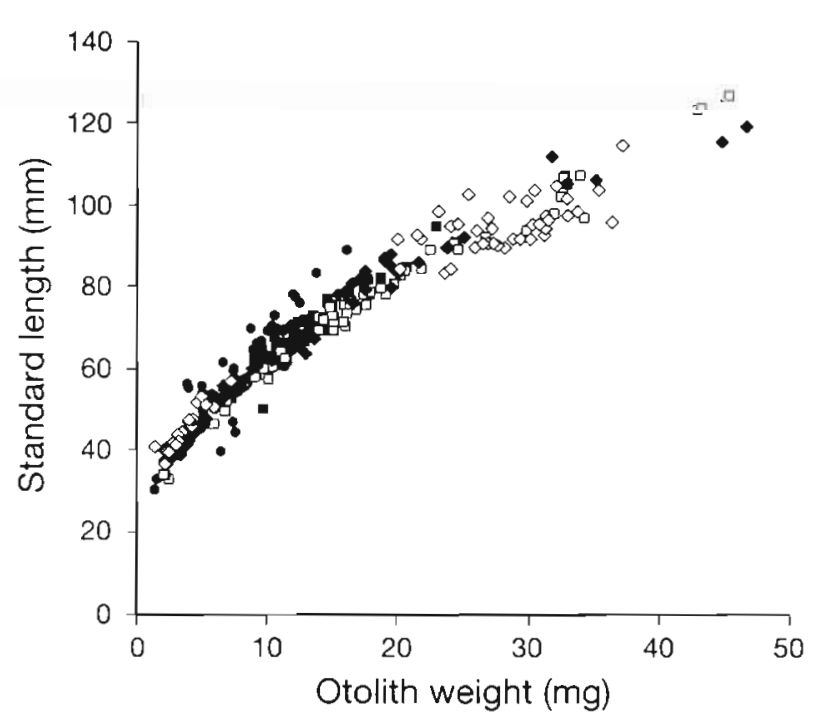

Fig. 5. Cynoscion regalis. Relationship between standard length and otolith weight for juvenile weakfish captured at Doboy Sound (ם), Pamlico Sound $(\bullet)$, Chesapeake Bay $(\bullet)$, Delaware Bay $(\diamond)$, and Peconic Bay (๘) 
Table 1. Cynoscion regalis. Summary information including collection site, collection date, number of fish analyzed ( $\mathrm{n}$ ), mean standard length (SL $[\mathrm{mm}], \pm \mathrm{SE})$, and otolith weight (OW $[\mathrm{mgl}, \pm \mathrm{SE}$ ) from juvenile weakfish captured at various locations along the U.S. Atlantic coast between July and September of 1996

\begin{tabular}{|lllllr|}
\hline Location & Site & Date & n & Mean SL & Mean OW \\
\hline Doboy Sound, Georgia & South River & 16 July 1996 & 23 & $69.8 \pm 4.4$ & $15.2 \pm 1.9$ \\
& Lower Duplin River & 17 July 1996 & 17 & $80.0 \pm 3.8$ & $19.1 \pm 2.0$ \\
& Upper Duplin River & 17 July 1996 & 13 & $82.2 \pm 4.1$ & $21.2 \pm 2.4$ \\
& Combined & & 53 & $76.1 \pm 2.6$ & $17.9 \pm 1.2$ \\
Pamlico Sound, North Carolina & Neuse River & 1 August 1996 & 25 & $49.5 \pm 3.4$ & $6.3 \pm 1.3$ \\
& Buff Shoals & 30 July 1996 & 29 & $77.1 \pm 3.2$ & $17.3 \pm 1.7$ \\
& Combined & & 54 & $64.3 \pm 3.0$ & $12.2 \pm 1.3$ \\
Chesapeake Bay, Virginia & James River & 10 July 1996 & 18 & $60.0 \pm 2.0$ & $9.2 \pm 0.7$ \\
& York River & 10 July 1996 & 23 & $64.1 \pm 2.5$ & $8.5 \pm 0.7$ \\
& Rappahannock River & 10 July 1996 & 12 & $54.2 \pm 3.0$ & $7.5 \pm 0.8$ \\
& Combined & & 53 & $60.5 \pm 1.5$ & $8.5 \pm 0.4$ \\
Delaware Bay, Delaware & Mouth & 20 September 1996 & 29 & $65.6 \pm 5.3$ & $12.9 \pm 2.4$ \\
& Lower Bay & 20 September 1996 & 18 & $87.1 \pm 3.7$ & $25.7 \pm 2.0$ \\
& Middle Bay & & 11 & $91.7 \pm 4.1$ & $26.6 \pm 2.4$ \\
Peconic Bay, New York & Combined & 8 July 1996 & 58 & $77.2 \pm 3.3$ & $19.5 \pm 1.6$ \\
& & & 56 & $67.8 \pm 1.0$ & $12.4 \pm 0.4$ \\
\hline
\end{tabular}

creasing epoch number and the computer time required to run the model for large numbers of epochs. All ANNs were performed using MATLAB's neural network toolbox (Demuth \& Beale 1994).

\section{RESULTS}

Juvenile weakfish collected throughout the sampling locations ranged in size from approximately 30 to $120 \mathrm{~mm}$ SL (Table 1). There were, however, no significant differences in either standard length (ANOVA: $\mathrm{df}=4,7 ; \mathrm{MS}=4360 ; \mathrm{p}=0.3042$ ) or otolith weight ( $\mathrm{ANOVA}: \mathrm{df}=4,7 ; \mathrm{MS}=1467 ; \mathrm{p}=0.1610$ ) among locations. Similarly, fish from all the locations had a similar standard length/otolith weight relationship (Fig. 5). Correlation coefficients between otolith weight and chemical variables were calculated for each site, and these correlations were then averaged to give a mean correlation coefficient for each location (Fig. 6). Although mean coefficients ranged from 0.4 to $-0.8,23$ of 30 coefficients were negative, indicating lower values for most of the elemental and isotopic variables with increasing otolith weight at most locations. Significant variability in the slopes of the relationship between otolith weight and each of individual elements and isotopes among locations meant, however, that we could not correct for the effect of otolith weight by using an analysis of covariance. It should be noted that variability in slopes among locations implies that there is little variation in trace element and isotopic signatures that can be attributed to a systematic effect of otolith weight on chemical signatures. We assumed, there- fore, that any relationship between otolith chemistry and fish or otolith size (or growth rate) would not confound any differences in chemical signatures among locations.

\section{Trace element chemistry}

Elemental data from otoliths showed significant variations, both at sites within locations and among loca-

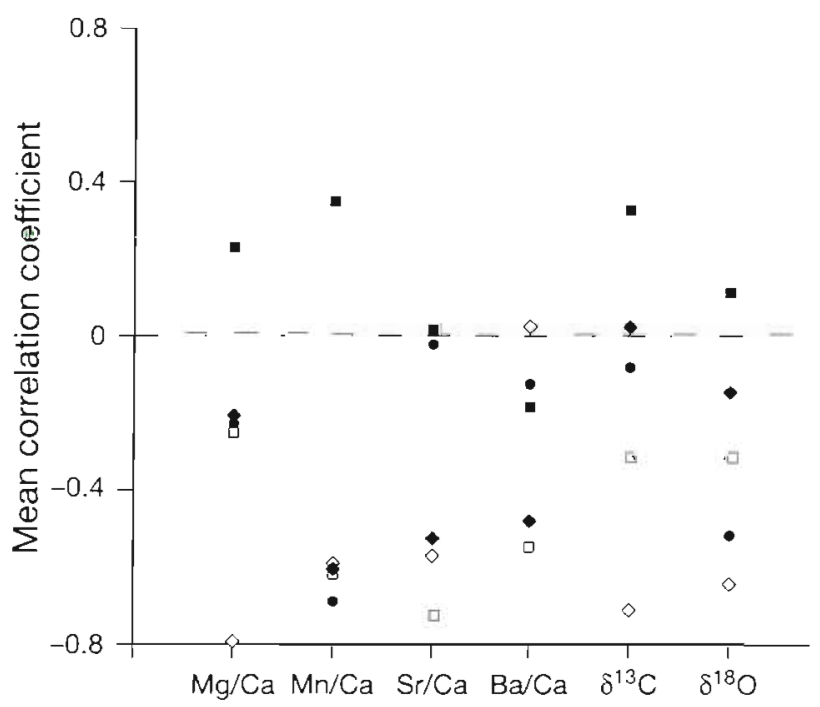

Fiø. 6. Cynoscion regalis. Mean correlation coefficients, averaged across sites, between chemical signatures and otolith weight from juvenile weakfish captured at Doboy Sound (D), Pamlico Sound $(\bullet)$, Chesapeake Bay $(\bullet)$, Delaware Bay $(0)$. and Peconic Bay (- 

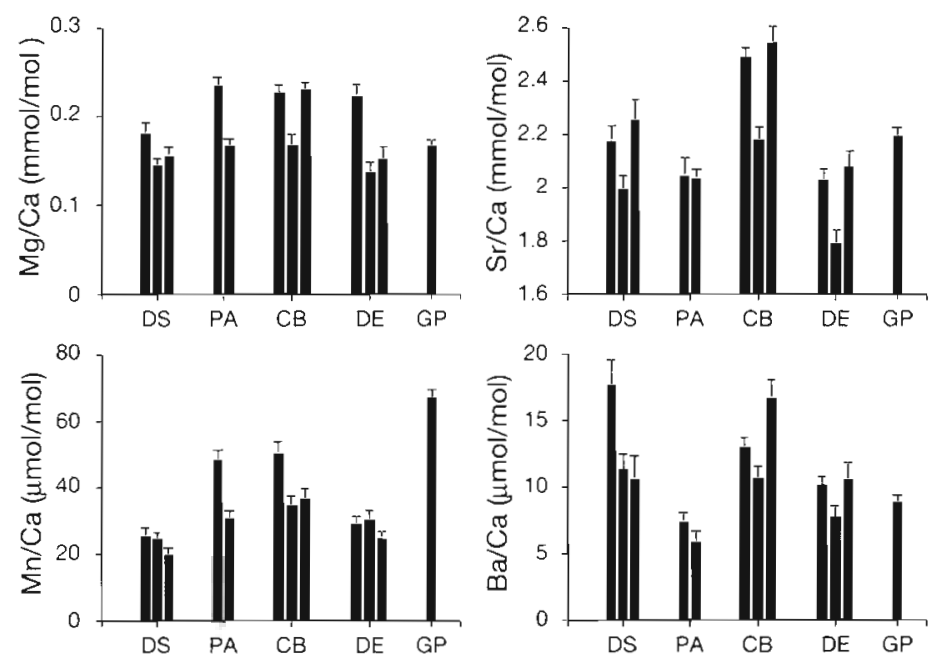

Fig. 7. Cynoscion regalis. Mean concentration, expressed as a ratio to $\mathrm{Ca}(+\mathrm{SE})$, of 4 elements in otoliths of juvenile weakfish collected from the different sites listed in Table 1 at Doboy Sound (DS), Pamlico Sound (PA), Chesapeake Bay (CB), Delaware Bay (DE), and Peconic Bay (GP)

tions (Fig. 7). A MANOVA found significant differences among sites nested within locations, and also significant differences among locations (Table 2). We used CDA to reduce the multivariate separation of the elemental signatures to fewer dimensions (Fig. 8). Bootstrapped $95 \%$ confidence ellipses around the class means on the first 2 canonical variates showed that none of the ellipses overlapped, suggesting significant variations in trace element signatures among all 5 locations. Fish from Peconic Bay were readily distinguishable from all other locations on the first canonical variate (CV1), while Pamlico Sound and Chesapeake Bay fish grouped together, as did Doboy Sound and Delaware Bay, along CV1. Canonical coefficients from CV1 showed that these separations contrasted $\mathrm{Mn} / \mathrm{Ca}$ ratios (positive values) with $\mathrm{Ba} / \mathrm{Ca}$ and $\mathrm{Mg} / \mathrm{Ca}$ ratios (negative values). The second canonical variate (CV2) in turn separated Pamlico Sound from Chesapeake Bay samples, and Doboy Sound fish from those collected in Delaware Bay. Canonical coefficients from CV2 showed that these differences were largely a contrast between $\mathrm{Sr} / \mathrm{Ca}$ ratios (positive values on $\mathrm{CV} 2$ ) and $\mathrm{Mg} / \mathrm{Ca}$ ratios (negative values on CV2).

Both LDFA and ANN were used to determine if differences among locations were sufficient to allow accurate classification of individual fish to their natal estuary system (Table 3 ). Classification error rates using LDFA ranged from $50 \%$, for fish collected from Pamlico Sound, to $16 \%$, for samples from
Peconic Bay. The ANN provided similar results, although with somewhat better classification success rates. Fish from Delaware Bay proved most difficult to accurately classify for ANN (43\% error rate), while Peconic Bay fish were again most easy to distinguish $(12 \%$ error rate). The overall error rate of the LDFA analysis was $36.8 \%$, while the ANN error rate was $29.6 \%$.

\section{$\delta^{13} \mathrm{C}$ and $\delta^{18} \mathrm{O}$ values}

Carbon isotope values in juvenile Cynoscion regalis otoliths ranged from approximately -9 to $0 \%$, while oxygen isotope values ranged from -8 to $0 \%$ (Fig. 9). There were considerable variations in both $\delta^{13} \mathrm{C}$ and $\delta^{18} \mathrm{O}$ among locations, as well as considerable variation at the site level in some, but not all, of the locations. For instance, $\delta^{13} \mathrm{C}$ values from samples within Delaware Bay spanned nearly the entire range of values across all locations. Samples from Doboy Sound showed very little variation both within and among sites. Oxygen isotope values were also highly variable in the Delaware Bay samples, but showed significantly less variation within and among sites at all other locations.

When $\delta^{13} \mathrm{C}$ and $\delta^{18} \mathrm{O}$ values were added to the elemental data set, the resulting MANOVA found highly significant differences both at the site and location level (Table 2). The associated CDA analysis showed almost complete separation among locations (Fig. 10) when the first 3 canonical variates were plotted. The only locations not well separated on the CV1 and CV2 were Pamlico Sound and Doboy Sound. However, these locations were clearly distinguishable on CV3. Canonical coefficients revealed that CV1 was principally a contrast between $\delta^{18} \mathrm{O}$ (positive values) and $\mathrm{Mn} / \mathrm{Ca}$ (negative values), CV2 contrasted $\delta^{13} \mathrm{C}$ and
Table 2. Results from MANOVA of element/Ca ratios, and $\delta^{13} \mathrm{C}$ and $\delta^{18} \mathrm{O}$ values, quantified in juvenile Cynoscion regalis otoliths from sites at locations along the U.S. Atlantic coast. All significance tests used Pillai's trace statistic. Note that the denominator for the Location $F$ approximation is the Site(Location) term, while the error term is the denominator in the Site(Location) $F$ approximation

\begin{tabular}{|c|c|c|c|c|c|}
\hline Source & Value & $F$ & Num df & Den df & $\mathrm{p}$ \\
\hline \multicolumn{6}{|c|}{ Dependent variables: $\mathrm{Mg} / \mathrm{Ca}, \mathrm{Mn} / \mathrm{Ca}, \mathrm{S}$ г/Ca and $\mathrm{Ba} / \mathrm{Ca}$} \\
\hline Location & 2.225 & 2.19 & 16 & 28 & 0.0333 \\
\hline Site(Location) & 0.784 & 9.12 & 28 & 1048 & 0.0001 \\
\hline \multicolumn{6}{|c|}{ Dependent variables: $\mathrm{Mg} / \mathrm{Ca}, \mathrm{Mn} / \mathrm{Ca}, \mathrm{Sr} / \mathrm{Ca}, \mathrm{Ba} / \mathrm{Ca}, \delta^{13} \mathrm{C}$ and $\delta^{18} \mathrm{O}$} \\
\hline Location & 3.562 & 6.20 & 24 & 20 & 0.0001 \\
\hline Site(Location) & 1.167 & 8.31 & 42 & 1446 & 0.0001 \\
\hline
\end{tabular}




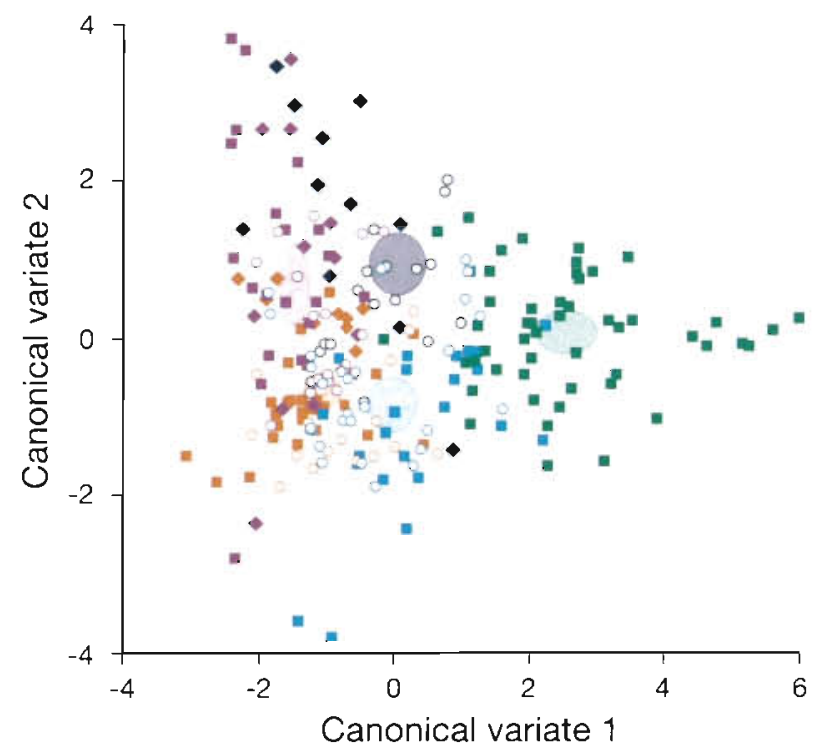

Fig. 8. Cynoscion regalis. Canonical variates 1 and 2, summarizing variations in trace element signatures of juvenile weakfish otoliths collected from Doboy Sound ( $=$ ), Pamlico Sound ( ( ), Chesapeake Bay ("), Delaware Bay (") and Peconic Bay ( $=$ ). Symbol colors map to individual locations, while symbol shapes indicate different sites within a location. Shaded areas represent bootstrapped $95 \%$ confidence ellipses around location means for each variate

$\mathrm{Mn} / \mathrm{Ca}$ ratios (positive values) with $\mathrm{Mg} / \mathrm{Ca}$ ratios (negative values), and finally $\mathrm{CV} 3$ contrasted $\delta^{13} \mathrm{C}$ and $\mathrm{Ba} / \mathrm{Ca}$ ratios (positive values) with $\mathrm{Mg} / \mathrm{Ca}$ and $\mathrm{Mn} / \mathrm{Ca}$ ratios (negative values). As a further check of the pos-

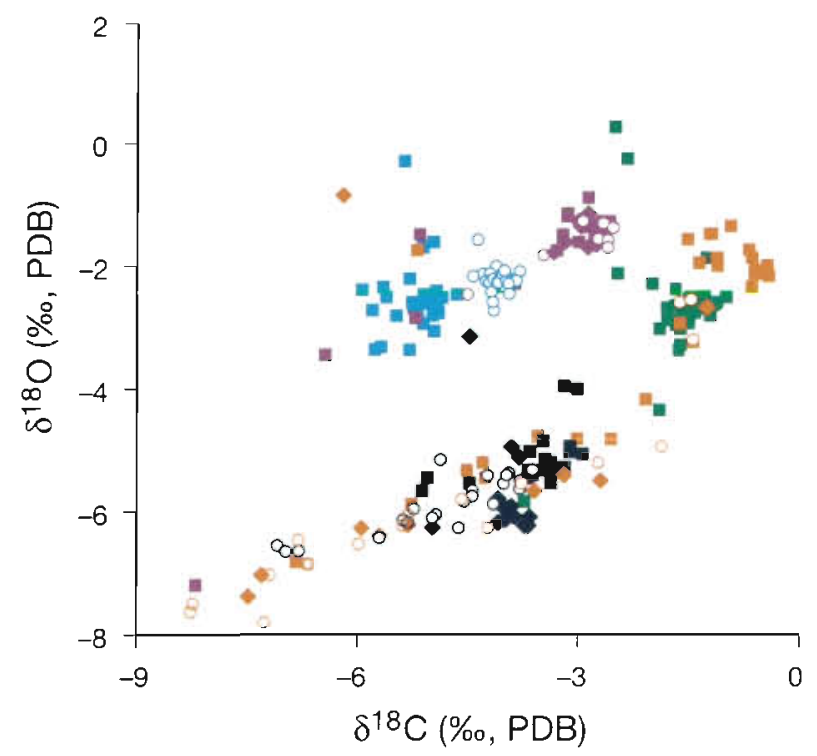

Fig. 9. Cynoscion regalis. Variations in $\delta^{13} \mathrm{C}$ and $\delta^{18} \mathrm{O}$ from otoliths of juvenile weakfish collected from Doboy Sound $(\varpi)$, Pamlico Sound ( $₫$ ), Chesapeake Bay (-), Delaware Bay ( $=$ ) and Peconic Bay (-). Different symbol shapes indicate different sites within a location
Table 3. Results of linear discriminant function (LDFA) and artificial neural network (ANN) analyses for classifying juvenile Cynoscion regalis to natal estuary based on trace element and isotopic signatures in otoliths. Samples came from Doboy Sound (DS), Pamlico Sound (PA), Chesapeake Bay (CB), Delaware Bay (DE) and Peconic Bay (GP). Bold values indicate percent of individuals successfully classified to their natal estuary $(n=$ number of samples analyzed)

\begin{tabular}{|c|c|c|c|c|c|c|}
\hline \multicolumn{2}{|c|}{ From location: } & DS & PA & $\mathrm{CB}$ & $\mathrm{DE}$ & $G P$ \\
\hline \multicolumn{7}{|c|}{$\begin{array}{l}\text { Cross-validation results }(\%) \text { with } \mathrm{Mg} / \mathrm{Ca}, \mathrm{Mn} / \mathrm{Ca} \text {, } \\
\mathrm{Sr} / \mathrm{Ca} \text { and } \mathrm{Ba} / \mathrm{Ca} \text { as dependent variables }\end{array}$} \\
\hline $\mathrm{DS}(\mathrm{n}=53)$ & $\begin{array}{l}\text { LDFA } \\
\text { ANN }\end{array}$ & $\begin{array}{l}56.6 \\
73.6\end{array}$ & $\begin{array}{l}3.8 \\
5.6\end{array}$ & $\begin{array}{l}7.6 \\
7.6\end{array}$ & $\begin{array}{l}32.1 \\
13.2\end{array}$ & $\begin{array}{l}0 \\
0\end{array}$ \\
\hline $\mathrm{PA}(\mathrm{n}=54)$ & $\begin{array}{l}\text { LDFA } \\
\text { ANN }\end{array}$ & $\begin{array}{l}3.7 \\
5.6\end{array}$ & $\begin{array}{l}50.0 \\
64.4\end{array}$ & $\begin{array}{r}13.0 \\
3.7\end{array}$ & $\begin{array}{l}25.9 \\
11.1\end{array}$ & $\begin{array}{r}7.4 \\
14.8\end{array}$ \\
\hline $\mathrm{CB}(\mathrm{n}=53)$ & $\begin{array}{l}\text { LDFA } \\
\text { ANN }\end{array}$ & $\begin{array}{r}7.6 \\
13.2\end{array}$ & $\begin{array}{l}9.4 \\
5.7\end{array}$ & $\begin{array}{l}66.0 \\
69.8\end{array}$ & $\begin{array}{l}9.4 \\
5.7\end{array}$ & $\begin{array}{l}7.6 \\
5.7\end{array}$ \\
\hline $\mathrm{DE}(\mathrm{n}=58)$ & $\begin{array}{l}\text { LDFA } \\
\text { ANN }\end{array}$ & $\begin{array}{l}15.5 \\
15.5\end{array}$ & $\begin{array}{l}17.2 \\
19.0\end{array}$ & $\begin{array}{l}6.9 \\
6.9\end{array}$ & $\begin{array}{l}58.6 \\
56.9\end{array}$ & $\begin{array}{l}1.7 \\
1.7\end{array}$ \\
\hline $\mathrm{GP}(\mathrm{n}=56)$ & $\begin{array}{l}\text { LDFA } \\
\text { NNA }\end{array}$ & $\begin{array}{l}0 \\
0\end{array}$ & $\begin{array}{l}5.4 \\
8.9\end{array}$ & $\begin{array}{r}10.7 \\
3.6\end{array}$ & $\begin{array}{l}0 \\
0\end{array}$ & $\begin{array}{l}83.9 \\
87.5\end{array}$ \\
\hline \multicolumn{7}{|c|}{$\begin{array}{l}\text { Cross-validation results }(\%) \text { with } \mathrm{Mg} / \mathrm{Ca}, \mathrm{Mn} / \mathrm{Ca} \text {, } \\
\mathrm{Sr} / \mathrm{Ca}, \mathrm{Ba} / \mathrm{Ca}, \delta^{13} \mathrm{C} \text { and } \delta^{18} \mathrm{O} \text { as dependent variables }\end{array}$} \\
\hline $\operatorname{DS}(n=49)$ & $\begin{array}{l}\text { LDFA } \\
\text { ANN }\end{array}$ & $\begin{array}{l}87.8 \\
87.8\end{array}$ & $\begin{array}{r}10.2 \\
6.1\end{array}$ & $\begin{array}{l}0 \\
2.0\end{array}$ & $\begin{array}{l}2.0 \\
4.1\end{array}$ & $\begin{array}{l}0 \\
0\end{array}$ \\
\hline $\mathrm{PA}(\mathrm{n}=51)$ & $\begin{array}{l}\text { LDFA } \\
\text { ANN }\end{array}$ & $\begin{array}{r}11.8 \\
2.0\end{array}$ & $\begin{array}{l}88.2 \\
98.0\end{array}$ & $\begin{array}{l}0 \\
0\end{array}$ & $\begin{array}{l}0 \\
0\end{array}$ & $\begin{array}{l}0 \\
0\end{array}$ \\
\hline$C B(r)=48)$ & $\begin{array}{l}\text { LDFA } \\
\text { ANN }\end{array}$ & $\begin{array}{l}0 \\
0\end{array}$ & $\begin{array}{l}0 \\
0\end{array}$ & $\begin{array}{l}85.4 \\
93.8\end{array}$ & $\begin{array}{r}12.5 \\
6.2\end{array}$ & $\begin{array}{l}2.1 \\
0\end{array}$ \\
\hline $\mathrm{DE}(\mathrm{n}=54)$ & $\begin{array}{l}\text { LDFA } \\
\text { ANN }\end{array}$ & $\begin{array}{l}1.9 \\
1.9\end{array}$ & $\begin{array}{l}1.9 \\
1.9\end{array}$ & $\begin{array}{r}13.0 \\
5.6\end{array}$ & $\begin{array}{l}81.5 \\
87.0\end{array}$ & $\begin{array}{l}1.9 \\
3.7\end{array}$ \\
\hline $\mathrm{GP}(\mathrm{n}=51)$ & $\begin{array}{l}\text { LDFA } \\
\text { NNA }\end{array}$ & $\begin{array}{l}0 \\
1.9\end{array}$ & $\begin{array}{l}3.8 \\
2.0\end{array}$ & $\begin{array}{l}2.0 \\
1.9\end{array}$ & $\begin{array}{l}2.0 \\
2.0\end{array}$ & $\begin{array}{l}92.2 \\
92.2\end{array}$ \\
\hline
\end{tabular}

sible influence of differences in otolith weight among locations on the otolith chemical signatures, we calculated Pearson correlation coefficients between otolith weight (OW) and each of the 3 canonical variates. Coefficients for each of the 3 variates were low $(\mathrm{CV} 1: \mathrm{OW}=0.18, \mathrm{CV} 2: \mathrm{OW}=-0.17, \mathrm{CV} 3: \mathrm{OW}=0.24)$, suggesting that the effect of otolith weight on the resulting CDA analysis was negligible.

The increased separation among locations seen in the CDA plots was reflected in reduced error rates of both LDFA and ANN when the combined data matrix, consisting of 4 element/Ca ratios and $\delta^{13} \mathrm{C}$ and $\delta^{18} \mathrm{O}$ values, was used to classify samples according to natal estuary (Table 3). LDFA error rates were less than $20 \%$ for all locations. Delaware Bay fish proved most difficult to classify (18\% error rate), while Peconic Bay fish were again classified most accurately ( $8 \%$ error rate). The ANN also showed better classification successes with the combined data set, with error rates ranging from 13\% (Delaware Bay) to 2\% (Pamlico Sound). Overall error rates were again lower with ANN (7\% error rate) than LDFA (13\% error rate). 

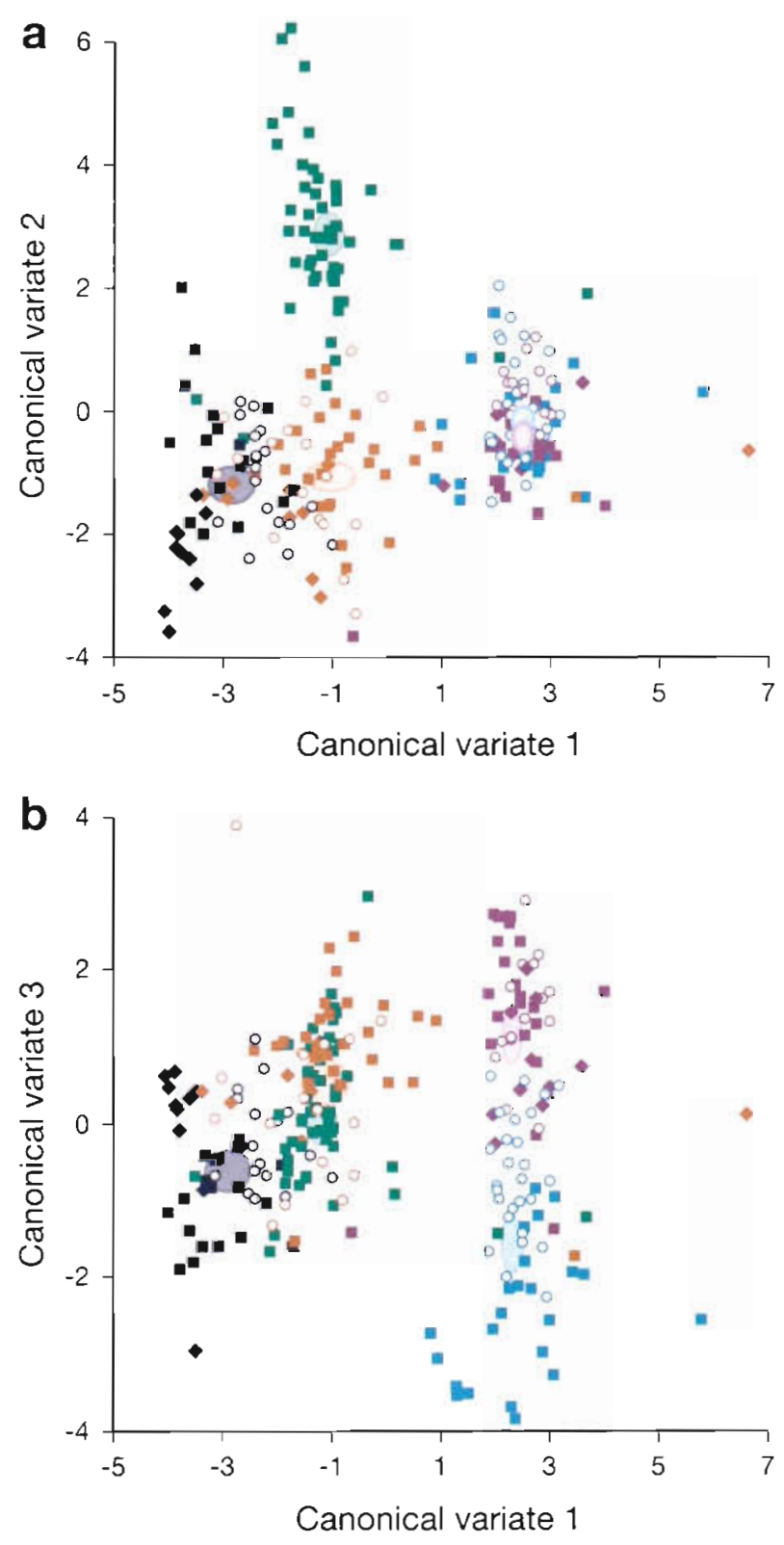

Fig. 10. Cynoscion regalis. (a) Canonical variates 1 and 2 and (b) canonical variates 1 and 3 , summarizing variations in trace element signatures combined with $\delta^{13} \mathrm{C}$ and $\delta^{18} \mathrm{O}$ values from juvenile weakfish otoliths collected from Doboy Sound ("), Pamlico Sound ("), Chesapeake Bay ("), Delaware Bay (") and Peconic Bay $(\pi)$. Different symbol shapes indicate different sites within a location. Shaded areas represent bootstrapped $95 \%$ confidence ellipses around location means for each variate

\section{Chesapeake Bay rivers}

The highly significant differences in chemical signatures among sites at some locations suggested that otolith chemistry may vary over smaller spatial scales as well as among locations. To examine this in more detail, we used samples collected from 3 rivers that

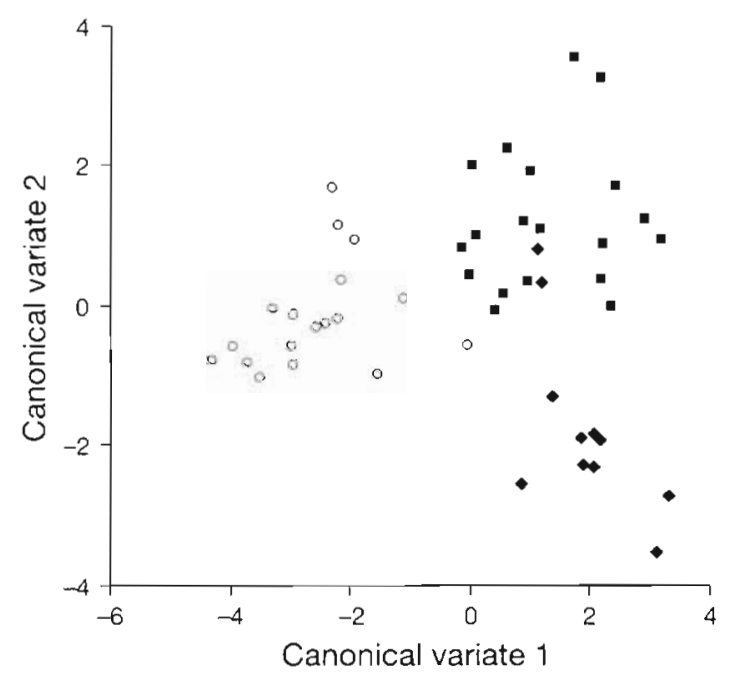

Fig. 11. Cynoscion regalis. Canonical variates 1 and 2 , summarizing variations in trace element signatures combined with $\delta^{13} \mathrm{C}$ and $\delta^{18} \mathrm{O}$ values from juvenile weakfish otoliths from the James River (0), the York River ( $\bullet$ ), and the Rappahannock River (*)

flow into the western shore of Chesapeake Bay - the James, York and Rappahannock Rivers. While sample sizes were smaller than the among location comparisons, CDA plots still showed that there was considerable separation among the rivers using the combined elemental and isotopic data (Fig. 11). Indeed, only 2 fish from the Rappahannock River overlapped in discriminant space with fish from the York River; the remaining 52 samples separated clearly into the specific river in which they were captured.

\section{DISCUSSION}

The elemental and isotopic composition of juvenile Cynoscion regalis otoliths varied considerably both within and among the estuarine systems we sampled. The most important finding in the present study was that chemical signatures in otoliths from each of the estuaries were distinct enough to be used as a natural mark of nursery area, despite statistically significant variations at sites within each location. By combining analyses of trace elements with carbon and oxygen isotope values, we were able to generate more powerful classification algorithms than if we had used the trace element data alone. It remains to be seen if the enhanced accuracy of the carbon and oxygen stable isotopes comes at the expense of higher error rates due to inter-annual variations within the different estuarine systems.

Oxygen isotopes in fish otoliths are deposited approximately in equilibrium with the $\delta^{18} \mathrm{O}$ values of 
ambient water $\left(\delta^{18} \mathrm{O}_{w}\right)$, with a temperature-dependent fractionation of $0.2 \%$ per ${ }^{\circ} \mathrm{C}$ (Patterson et al. 1993, Thorrold et al. 1997b). Mean temperature differences among locations in the present study varied by a maximum of $7^{\circ} \mathrm{C}$, while $\delta^{18} \mathrm{O}$ values in otoliths ranged from 0 to $-8 \%$. It appears, then, that temperature effects on $\delta^{18} \mathrm{O}$ fractionation were overwhelmed by differences in the oxygen isotopic composition of the ambient water $\left(\delta^{18} \mathrm{O}_{w}\right)$. Oxygen isotopic values of estuarine waters are negatively correlated with salinity, and are also influenced by a latitudinal gradient in the $\delta^{18} \mathrm{O}$ of meteoric waters (Hoefs 1980). We found that otoliths with depleted $\delta^{18} \mathrm{O}$ values were almost invariably from locations where fish were exposed to significant amounts of fresh water, suggesting that the otoliths were faithfully recording the isotopic signature of the water in the nursery areas.

Geographic differences in carbon isotopes are more difficult to interpret than $\delta^{18} \mathrm{O}$ variations, largely because of the nature of carbon incorporation in otoliths. Carbon isotopes in fish otoliths are almost always significantly depleted in $\delta^{13} \mathrm{C}$ compared to $\delta^{13} \mathrm{C}$ values of dissolved inorganic carbon $\left(\delta^{13} \mathrm{C}_{\mathrm{DIC}}\right)$ in the ambient environment (Kalish 1991a, Thorrold et al. 1997b). These studies concluded that some metabolic carbon. along with carbon from DIC sources, is incorporated in otoliths. Otolith $\delta^{13} \mathrm{C}$ values could therefore reflect either variations in $\delta^{13} \mathrm{C}_{\mathrm{DIC}}$ of the environment or, alternatively, differences in the incorporation rates of metabolic carbon. Significant correlations between fish growth, otolith growth and $\delta^{13} \mathrm{C}$ in juvenile Micropogonias undulatus, after correcting for $\delta^{13} \mathrm{C}_{\mathrm{D} 1 \mathrm{C}}$, demonstrate that otolith $\delta^{13} \mathrm{C}$ is related to physiological processes as well as ambient environmental variables (Thorrold et al. 1997b). However, the data from Delaware Bay provide evidence that the isotopic composition of DIC may also effect $\delta^{13} \mathrm{C}$ values in otoliths. The plot of otolith $\delta^{13} \mathrm{C}$ and $\delta^{18} \mathrm{O}$ values revealed that fish from Delaware Bay fall into 1 of 2 distinct groupings. The first grouping was indicative of a predominantly seawater end member, with $\delta^{13} \mathrm{C}$ values around $-1 \%$, and $\delta^{18} \mathrm{O}$ values of approximately $-2 \%$. The second grouping was characterized by a linear relationship between $\delta^{13} \mathrm{C}$ and $\delta^{18} \mathrm{O}$, with $\delta^{13} \mathrm{C}$ values ranging from -8.5 to $-2 \%$, and $\delta^{18} \mathrm{O}$ values ranging from -8 to $-4 \%$. Several lines of evidence suggest that juvenile weakfish do not move large distances within Delaware Bay once they have settled out of the plankton (Grecay \& Targett 1996). We suspect, therefore, that this second grouping contained fish that had resided in specific areas along the estuarine gradient from the lower estuary (salinity approximately $30 \%$ ) to the tidal reaches of the Delaware River (salinity $<10 \%$ ), as juvenile weakfish are common throughout this range (Grecay 1990). Carbon isotope ratios of DIC in Delaware co-vary with salinity, ranging from $0 \%$ at the Bay mouth to between -10 and to $-11 \%$ in the tidal areas of the Delaware River (Fogel et al. 1992). Fish from the upper Bay areas had, then, presumably recently migrated from these areas to mid and lower Bay sampling sites as part of the annual fall migration from estuarine nursery habitats to more southern coastal waters.

The mechanisms generating observed geographic differences in trace element composition of otoliths are not well understood. Levels of minor and trace elements in otoliths may be related to variations in the ambient water chemistry of the estuaries as modified by temperature (Thorrold et al. 1997a), differences in the diet of juveniles among locations (Limburg 1995), or to physiological effects that regulate ion concentrations in the blood plasma (Kalish 1991b). We do not have sufficient information to eliminate any of these hypotheses. However, the lack of any detectable differences in a RFLP (restriction fragment length polymorphism) mtDNA study of juvenile Cynoscion regalis argues that any physiological differences among juveniles from the different estuaries do not have a genetic basis (Graves et al. 1992). Evidence for the role of diet in determining otolith chemistry is mixed in the literature. Although Limburg (1995) found that Sr/Ca levels in the otoliths of juvenile Alosa sapidissima were sensitive to changes in Sr/Ca levels in the diet, 2 other studies have recently found that $\mathrm{Sr}$ from dietary sources contributed little to otolith Sr (Hoff \& Fuiman 1995, Farrell \& Campana 1996).

Several studies have suggested that either fish growth rates or otolith precipitation rates may influence otolith composition (e.g. Sadovy \& Severin 1992, Fowler et al. 1995, Thorrold et al. 1998). Given that otolith and fish growth is almost always highly colinear, it has been impossible to examine either in isolation. Certainly the preponderance of negative correlations between chemical signatures and otolith weight argues that this hypothesis requires investigation. Several possible scenarios could result in a significant relation between the otolith weight and elemental or isotopic signatures. Firstly, the incorporation rate of an element (or isotope) may be dependent upon the precipitation rate of aragonite on the otolith, as has been suggested for Sr/Ca ratios in coral skeletons (de Villiers et al. 1995). Second, larger fish, with concomitantly larger otoliths, may be better able to discriminate against calcium analogs such as Sr at some stage during the movement of ions from seawater to the depositional surface of the otolith. However, neither explanation can be advanced for the negative relationship between $\delta^{18} \mathrm{O}$ values and otolith weight, as oxygen isotopes are generally considered to be deposited in equilibrium with the environment and are independent of precipitation rate (Thorrold et al. 
1997 b). Finally, as analysis of whole otoliths invariably loses information on size-specific migration patterns, it is possible that larger juveniles are moving into waters of differing elemental or isotopic composition than smaller fish. This is an adequate explanation for the $\delta^{13} \mathrm{C}$ and $\delta^{18} \mathrm{O}$ data (see above) and the observation that some locations (e.g. Peconic Bay) consistently showed low and positive correlations between otolith weight and elemental signatures while other locations (e.g. Delaware Bay) consistently showed high, negative correlations between the same variables.

We were surprised to see such clear differences in otolith chemical signatures among the 3 rivers sampled in Chesapeake Bay. However, there were also significant differences in salinity regimes in these rivers during the late spring and summer of 1996 (Fig. 2). The proximity of the James River to the mouth of Chesapeake Bay meant that high salinities (up to $27 \%$ ) were observed during periods of low freshwater input. However, during periods of high freshwater input, salinities in the lower James River approached 0\%. The York River showed less salinity variation than the James River, although salinities as high as $20 \%$ were recorded in the lower reaches during May 1996, indicating significant exchange with Chesapeake Bay water. The Rappahannock River has a shallow sill at its mouth, which acts to restrict water exchange with Chesapeake Bay. Average salinity values in the lower Rappahannock during 1996 were, therefore, lower than either the James or York Rivers, and also showed the smallest range around the mean. We hypothesize that differences in dissolved metal levels among the rivers, as indicated by salinity, were sufficient to generate the observed differences in trace element signatures in the otoliths of juvenile weakfish. Although definitive data on the trace element composition of these waters is lacking, we plan on collecting this data in the near future to test the relationships between trace element chemistry and levels of dissolved metals present in the different water masses.

While a number of workers have clearly demonstrated the potential of otolith chemistry to distinguish among adjacent adult fish populations (e.g. Edmonds et al. 1989, Campana et al. 1995), it has proved more difficult to demonstrate that chemical signatures may also be useful as a natural marker of juvenile nursery or natal spawning area of individual fish (Campana et al. 1994, Thresher et al. 1994, Proctor et al. 1995, Severin et al. 1995, Gillanders \& Kingsford 1996). The results of this study, and results from similar work on juvenile Alosa sapidissima, argue that elemental and isotopic signatures in otoliths can indeed record the natal areas of individual fish with error rates of less than $10 \%$ (Thorrold et al. 1998). We also saw a reduction in error rates of between 5 and $7 \%$ with the use of
ANN to classify unknown samples when compared to LDFA. Although this is the first time that ANN has been used in an otolith chemistry application, similar improvements in classification success rates were reported in a chemostratigraphy study that also compared ANN with LDFA (Malmgren \& Nordlund 1996). It should be noted that ANNs are well suited for handling genetic information as well. It would, therefore, be easy to merge data from DNA markers with otolith chemistry signatures into a single matrix for input into an ANN model, as can be done with maximum likelihood estimation procedures.

There are important implications for the interpretation of chemical signatures in otoliths if, as we believe, the signatures are largely determined by spatial variability in the physical environment. Significant differences in trace element and isotopic signatures among geographically separated groups do not imply reproductive isolation, as would such a finding based on genetic data. Rather, these data suggest that geographic isolation has persisted for a significant portion of an individual's life. Management strategies designed to conserve genetic diversity will need to continue to rely upon DNA analyses to delineate the spatial extent of genetic mixing. However, a significant problem with genetic markers is that ecologically inconsequential rates of genetic exchange, probably less than $1 \%$, are sufficient to maintain Hardy-Weinberg equilibrium among populations. This appears to be a common situation in marine fishes, in which geographically isolated populations are genetically linked by even small amounts of larval dispersal or adult vagrancy (e.g. Graves et al. 1992, Gold et al. 1997). An environmentally induced natural tag such as trace element or isotopic signatures in otoliths will allow fish ecologists to quantify exchange rates among meta-populations in situations where these rates could not be quantified using genetic approaches.

Acknowledgements. This work was funded in part by Virginian recreational and commercial fishing license funds, through the Virginia Marine Resources Commission. This work is also a result of research sponsored in part by the NOAA Office of Sea Grant, U.S. Department of Commerce, under Grant No. NA56RG0489 to the Virginia Graduate Marine Science Consortium and Virginia Sea Grant College Program. We thank L. Barbieri (University of Georgia), P. Geer (Virginia Institute of Marine Science), C. Grahn (New York Department of Environmental Conservation), $M$. Greene (NOAA/NMFS Beaufort Lab) and S. LowerreBarbieri (University of Georgia), for their generous help in collecting specimens for this study, and J. Sharp and D. Kirchman for providing temperature and sálinity data for Delaware Bay. D. Gray conducted the ID-ICPMS analyses, and A. Saied provided expert technical assistance with the stable isotope analyses. Comments by S. Campana and 2 anonymous reviewers significantly improved earlier drafts of the manuscript. 


\section{LITERATURE CITED}

Campana SE, Fowler AJ, Jones CM (1994) Otolith elemental fingerprinting for stock identification of Atlantic cod (Gadus morhua) using laser ablation ICPMS. Can J Fish Aquat Sci 51:1942-1950

Campana SE, Gagné JA, McLaren JW (1995) Elemental fingerprinting of fish otoliths using ID-ICPMS. Mar Ecol Prog Ser 122:115-120

Campana SE, Neilson JD (1985) Microstructure of fish otoliths. Can J Fish Aquat Sci 42:1014-1032

Campana SE, Thorrold SR, Jones CM, Günther D, Tubrett M,

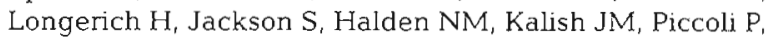
de Pontual H, Troadec H, Panfili J, Secor DH, Severin KP, Sie SH, Thresher R, Teesdale WJ, Campbell JL (1997) Comparison of accuracy, precision and sensitivity in elemental assays of fish otoliths using the electron microprobe, PIXE and laser ablation ICPMS. Can J Fish Aquat. Sci 54:2068-2079

Cornuet JM, Aulagnier S, Lek S, Franck P, Solignac M (1996) Classifying individuals among infra-specific taxa using microsatellite data and neural networks. C R Acad Sci Paris 319:1167-1177

Craig H (1957) Isotopic standards for carbon and oxygen and correction factors for mass-spectrometric analysis of carbon dioxide. Geochim Cosmochim Acta 12:133-149

Crawford MK, Grimes CB, Buroker NW (1988) Stock identification of weakfish. Cynoscion regalis, in the middle Atlantic region. Fish Bull US 87:205-211

Culverhouse PF, Ellis R, Simpson RG, Williams R, Pierce RW, Turner JT (1992) Automatic categorisation of five species of Cymatocylis (Protozoa, Tintinnida) by artificial neural network. Mar Ecol Prog Ser 107:273-280

Demuth H, Beale M (1994) Neural network toolbox for use with MATLAB. The Mathworks, Inc, Natick, MA

de Villiers S, Nelson BK, Chivas AR (1995) Biological controls on coral $\mathrm{Sr} / \mathrm{Ca}$ and $\delta^{18} \mathrm{O}$ reconstructions of sea surface temperatures. Science 269:1247-1249

Edmonds JS, Caputi N, Morita M (1991) Stock discrimination by trace-element analysis of otoliths of orange roughy (Holostethus atlanticus), a deep-water manine teleost. Aust J Mar Freshwat Res 42:383-389

Edmonds JS, Fletcher WJ (1997) Stock discrimination of pilchards Sardinops sagax by stable isotope ratio analysis of otolith carbonate. Mar Ecol Prog Ser 152:241-247

Edmonds JS, Lenanton RCJ, Caputi N, Morita M (1992) Trace elements in the otoliths of yellow-eye mullet (Aldrichetta forsteri) as an aid to stock identification. Fish Res 13:39-51

Edmonds JS, Moran MJ, Caputi N, Morita M (1989) Trace element analysis of fish sagittae as an aid to stock identification: pink snapper (Chrysophrys auratus) in Western Australian waters. Can J Fish Aquat Sci 46:50-54

Efron G, Gong G (1983) A leisurely look at the bootstrap, the jackknife and cross-validation. Am Stat 37:36-48

Farrell J, Campana SE (1996) Regulation of calcium and strontium deposition on the otoliths of juvenile tilapia, Oreochromis niloticus. Comp Biochem Physiol 115:103-109

Fogel ML, Cifuentes LA, Velinsky DJ, Sharp JH (1992) Relationship of carbon availability in estuarine phytoplankton to isotopic composition. Mar Ecol Prog Ser 82:291-300

Fowler AJ, Campana SE, Jones CM, Thorrold SR (1995) Experimental assessment of the effect of temperature and salinity on elemental composition of otoliths using solution-based ICPMS. Can J Fish Aquat Sci 52:1421-1430

Gillanders BM, Kingsford MJ (1996) Elements in otoliths may elucidate the contribution of estuarine recruitment to sustaining coastal reef populations of a temperate reef fish.
Mar Ecol Prog Ser 141:13-20

Gold JR, Sun F, Richardson LR (1997) Population structure of red snapper from the Gulf of Mexico as inferred from analysis of mitochondrial DNA. Trans Am Fish Soc 126: 386-396

Graves JE, McDowell JR, Jones ML (1992) A genetic analysis of weakfish Cynoscion regalis stock structure along the mid-Atlantic coast. Fish Bull US 90:469-475

Grecay PA (1990) Factors affecting spatial patterns of feeding success and condition of juvenile weakfish (Cynoscion regalis) in Delaware Bay: field and laboratory assessment. PhD dissertation, University of Delaware, Graduate College of Marine Studies, Lewes

Grecay PA, Targett TE (1996) Spatial patterns in condition and feeding of juvenile weakfish in Delaware Bay. Trans Am Fish Soc 125:803-808

Hoefs J (1980) Stable isotope geochemistry. Springer-Verlag, Berlin

Hoff GR, Fuiman LA (1995) Environmentally induced variation in elemental composition of red drum (Sciaenops ocellatus) otoliths. Bull Mar Sci 56:578-591

Kalish JM (1991a) ${ }^{13} \mathrm{C}$ and ${ }^{18} \mathrm{O}$ isotopic disequilibria in fish otoliths: metabolic and kinetic effects. Mar Ecol Prog Ser 75:191-203

Kalish JM (1991b) Determinants of otolith chemistry: seasonal variation in the composition of blood plasma, endolymph and otoliths of bearded rock cod Pseudophycis barbatus. Mar Ecol Prog Ser 74:137-159

Lea DW, Boyle EA (1993) Reply to the comment by N.E. Pingitore Jr. on 'Barium in planktonic foraminifera.' Geochim Cosmochim Acta 57:471-473

Lea DW, Martin PA (1996) A rapid mass spectrometric method for the simultaneous analysis of barium, cadmium, and strontium in foraminifera shells. Geochim Cosmochim Acta 60:3143-3149

Limburg KE (1995) Otolith strontium traces environmental history of subyearling American shad Alosa sapidissima. Mar Ecol Prog Ser 119:25-35

Malmgren BA, Nordlund U (1996) Application of artificial neural networks to chemostratigraphy. Paleoceanography 11:505-512

Nelson CS, Northcote TG, Hendy CH (1989) Potential use of oxygen and carbon isotopic composition of otoliths to identify migratory and non-migratory stocks of the New Zealand common smelt: a pilot study, NZ J Mar Freshwat Res 23:337-344

Patterson WP, Smith GR, Lohmann KC (1993) Continental paleothermometry and seasonality using the isotopic composition of aragonitic otoliths of freshwater fishes. Geophys Monogr 78:191-202

Proctor CH, Thresher RE, Gunn JS, Mills DJ, Harrowfield IR, Sie SH (1995) Stock structure of the southern bluefin tuna Thunnus maccoyii: an investigation based on probe microanalysis of otolith composition. Mar Biol 122:511-526

Rowe PM, Epifanio CE (1994) Tidal stream transport of weakfish larvae in Delaware Bay, USA. Mar Ecol Prog Ser 110 : $105-114$

Sadovy Y, Severin KP (1992) Trace elements in biogenic aragonite: correlation of body growth rate and strontium levels in the otoliths of the white grunt, Haemulon plumieri (Pisces: Haemulidae). Bull Mar Sci 50:237-257

SAS Institute Inc. (1990) SAS/STAT user's guide, Version 6. SAS Institute Inc, Cary, NC

Severin KP, Carroll JL, Norcross BL (1995) Electron microprobe analysis of juvenile walleye pollock, Theragra chalcogramma, otoliths from Alaska: a pilot stock separation study. Environ Biol Fish 43:269-283 
Thorrold SR, Campana SE, Jones CM, McLaren JW, Lam JWH (1998) Trace element signatures in otoliths accurately record natal river of juvenile American shad (Alosa sapidissima). Limnol Oceanogr (in press)

Thorrold SR, Campana SE, Jones CM, Swart PK (1997b) Factors determining $\delta^{13} \mathrm{C}$ and $\delta^{18} \mathrm{O}$ fractionation in aragonitic otoliths of marine fish. Geochim Cosmochim Acta 61: $2909-2919$

Thorrold SR, Jones CM, Campana SE (1997a) Response of otolith microchemistry to environmental variations experienced by larval and juvenile Atlantic croaker (Micropogo-

Editorial responsibility: Otto Kinne (Editor),

Oldendort/Luhe, Germany nias undulatus). Limnol Oceanogr 42:102-111

Thresher RE, Proctor CH, Gunn JS, Harrowfield IR (1994) An evaluation of electron-probe microanalysis of otoliths for stock delineation and identification of nursery areas in a southern temperate groundfish, Nemadactylus macropterus (Cheilodactylidae). Fish Bull US 92:817-840

Vaughan DS, Seagraves RJ, West K (1991) An assessment of Atlantic weakfish stock, 1982-1988. Atlantic States Mar Fish Comm Spec Rep 21, Washington, DC

Winer B (1971) Statistical principles in experimental design, 2nd edn. McGraw-Hill, New York.

Submitted: March 9, 1998; Accepted: August 4, 1998

Proofs received from author(s): October 21, 1998 